\title{
Part-time Employment and Health Insurance Reform: What Can Massachusetts Tell Us about the Affordable Care Act?
}

\author{
Laura J. Owen $\mathrm{a}^{*}$ \\ a Economics Department, DePaul University, Chicago, IL 60604. \\ ${ }^{*}$ Corresponding author's email address: lowen@depaul.edu
}

\section{A R T I C L E I N F O}

Received: 23-02-2017

Accepted: 03-03-2017

Available online: 21-03-2017

Keywords:

Affordable Care Act;

Health reform;

Part-time employment.

JEL Classification:

$\mathrm{I} 13$; J22 ; J23

\begin{abstract}
A B S T R A C T
Experience with health insurance reform in Massachusetts may provide a good forecast of the impact of the Affordable Care Act [ACA] on the growth of part-time employment. Concerns have been expressed that the ACA will lead to growing part-time employment, but it will take several years to observe this effect and whether it is labor demand (firm) or labor supply (worker) initiated. Using state-level data from 1999 to 2012, I treat the 2007 implementation of the new Massachusetts health insurance system as an "experiment" to examine whether it had any differential effect on the growth in part-time employment in the state. A panel estimation including fixed cross-section and period effects reveals that voluntary part-time employment increased in Massachusetts relative to the other states, but reform measures did not have an effect on involuntary part-time employment. The impact of the reform on voluntary part-time employment suggests that some Massachusetts workers found the pre-reform system to be an obstacle to their choice of optimal work hours. The implementation of the ACA, by providing avenues for obtaining health insurance that are not directly tied to employment, may remove this obstacle for workers in other states and make part-time employment a more attractive choice for workers across the U.S.
\end{abstract}

This is an open access article under the terms of the Creative Commons Attribution License 4.0, which allows use, distribution and reproduction in any medium, provided the original work is properly cited.

DOI: http://dx.doi.org/10.18533/rss.v2i3.90

ISSN 2378-8569(Print), ISSN 2378-8550(Online)

\section{Introduction}

With the passage of the Affordable Care Act [ACA] in 2010 and its phased implementation, researchers began exploring the potential effects of this new healthcare legislation (see for example Gruber, 2011a). While many analyses examine the law's impact on insurance coverage, care utilization and health outcomes, others focus on its potential to affect labor demand (firm behavior) and labor supply (worker behavior) as well as wage determination (Aaronson \& Lubotsky, 2014). ${ }^{1}$ Concerns have been raised that provisions of the new health care law change the incentives of both workers and firms and may lead to growth in part-time employment (Mulligan, 2014). Even with the recent presidential election and the anticipated changes to the ACA, understanding the law's impact on labor markets is still crucial.

\footnotetext{
1 Aaronson \& Lubotsky (2014) summarize the papers presented at a March 21, 2014 symposium on the ACA and the labor market, co-sponsored by the Federal Reserve Bank of Chicago and the Institute of Government and Public Affairs of the University of Illinois. The conference papers and videos of presentations are available at www.chicagofed.org/webpages/events/2014/affordable_care_act.cfm.
} 
Two avenues by which the ACA might affect part-time employment contrast potential labor demand and labor supply causes. First, because employers are not required to offer health insurance to employees who work less than 30 hours per week, firms may have an incentive to employ more part-time workers as a means of reducing the costs of their health insurance benefits. Second, because individuals will have greater access to nonemployment based health insurance, workers desiring shorter hours may be able to choose part-time employment without sacrificing access to health insurance. These labor demand and labor supply arguments both predict the ACA may lead to growth in part-time employment.

It will take several years to observe whether the national legislation has a long-term effect on part-time employment growth and whether it is labor demand or labor supply induced. Jorgensen \& Baker (2014) report preliminary findings of an increase in part-time employment in the first six months of 2014 following the start of the individual mandate, but full implementation of the act did not occur until 2015 following a delay in the application of the employer mandate. Mathur, Slavov, \& Strain (2015) found no evidence that firms reduced the hours of their workers in anticipation of the employer mandate to provide health insurance for those working more than 30 hours per week, though they note that "the ACA could cause a shift towards part-time work in the future as the mandate takes effect" (Mathur, Slavov, \& Strain 2015, p. 1).

Other researchers have suggested that analyzing the earlier 2006 health insurance reform in Massachusetts can shed light on the future impact of the ACA (Gruber, 2011b; Heim \& Lurie, 2015; Kolstad \& Kowalski, 2016). In Massachusetts, health insurance reform-"An Act Providing Access to Affordable, Quality, Accountable Health Care," Chapter 58 of the Acts of 2006 [hereafter MA St. 2006, c.58]-passed on April 12, 2006 and was fully implemented by July 1,2007 . The law contains several of the same structural features that were later included in the ACA. Since the Massachusetts system has been in place for several years, an examination of its impact on parttime employment growth in that state can provide a potential forecast of the impact of the ACA on labor markets and hours of work. The following paper takes this approach by examining the growth in part-time employment in Massachusetts relative to all other states before and after the implementation of the state-level health insurance reform.

This introduction is followed by a literature review which discusses the relevant economic theory [of labor demand and labor supply] of part-time employment. This section also provides details on how the Massachusetts health reform law is similar to the ACA. The literature review is followed by a Data, Methods, and Findings section which discusses the original contribution of this paper. These findings are followed by a conclusion which discusses the policy relevance of these results both in terms of the ACA and the potential "repeal and replacement" of the current law.

\section{Literature review}

\subsection{Understanding part-time employment}

Firms may benefit from employing part-time workers through increased flexibility in labor staffing, lower total compensation costs, and better screening of workers. Part-time employment can be a source of cost savings by providing firms increased flexibility in responding to changes in product demand or a means of meeting peakhour or peak-day demand by supplementing full-time shifts with part-time workers. Employing part-time workers can reduce firms' labor compensation costs both in terms of wages paid and benefits provided, since parttime workers are often paid less than full-time workers and have less access to company-provided pensions and health insurance. The potential cost savings of employing part-time workers may be limited by the legislated minimum wage. Additionally, firms may use initial part-time employment as a probationary period prior to offering full-time employment, a strategy that allows firms to observe workers and assess their productivity before offering the higher wage and benefit packages of full-time work. In this manner, part-time employment may allow firms to lower their screening costs and hire more productive workers into full-time positions (Blank, 1990; Duffy \& Pupo, 1992; Gallaway, 1995; Houseman, 2001).

Workers may seek out part-time employment as a means of balancing employment with other demands on their time, such as education, childcare, and retirement activities. Workers' desire for part-time employment often follows a life cycle pattern with younger workers desiring part-time employment as they balance income earning with school attendance and older workers seeking out part-time employment as a path to retirement. Workers with children may look to part-time employment as a means of combining the opportunity to earn income with childcare or other family responsibilities. However, the lower wages earned by part-time workers limit the income generation of this choice (Duffy \& Pupo, 1992; Marshall, 2001; Snider, 1995).

Recent growth in part-time employment has been met with mixed reactions. Those who see the phenomenon as primarily driven by firms' desire to reduce costs (labor demand considerations) often focus on the employment 
insecurity and lower compensation of part-time workers. Those who see the trend as driven by changes in the demographics of the work force (labor supply considerations) view part-time employment as a solution to worklife balance issues. This debate centers on whether the part-time employment is being voluntarily sought out by workers or whether they are involuntarily forced to accept part-time work. Involuntary part-time employment is both highly cyclical (rising during recessions) and a function of adequate employment growth, (without which an economy may find it hard to provide full-time employment for its labor force). However, the majority of part-time workers in the U.S. voluntarily choose part-time hours (Blank, 1990; Erhenberg, Rosenberg, \& Li, 1988; Kalleberg, Reskin, \& Hudson, 2000; Marshall, 2001; Pupo \& Duffy, 2000; Tilly, 1991).

An historical analysis comparing part-time employment growth in the U.S. and Canada from 1955 to 2000 (Owen, 2015) suggests that the U.S. employment-based system of providing health insurance through the workplace was an obstacle to workers' being free to choose optimal work arrangements. The link between employer-provided health insurance and labor mobility is the subject of a large body of literature by labor economists. (See Gruber \& Madrian 2004) for an earlier review of this literature and Heim \& Lurie (2015), Garthwaite, Gross \& Notowidigdo (2014), and Hamersma \& Kim (2009) for more recent analyses.) The term "job lock" has been used (Gruber \& Madrian, 1994) to describe the potential inefficiencies generated when employment-based health insurance ties workers to jobs for fear of losing coverage. Owen (2015) suggests that the U.S. employment-based health insurance system (in contrast to Canada's residence-based system) may have another unintentional consequence: restricting the choice of part-time versus full-time work [an "hours lock"]. In fact, if employers are providing health insurance to their workers these premiums become a quasi-fixed cost [per worker not per hour] and may lead to firms preferring to hire full-time over part-time workers (Cutler \& Madrian, 1998). The implementation of the ACA, which will provide avenues for obtaining health insurance that are not directly tied to employment (including the state exchanges, Medicaid expansion, and expanded dependent coverage), may directly address any "hours lock" and make part-time employment a more attractive choice for U.S. workers in the future. ${ }^{2}$

The nationwide expansion of dependent coverage [allowing children to remain on a parent's policy until age 26] was implemented soon after the passage of the ACA legislation, though some states had previously expanded dependent coverage. Studies of these earlier state-level expansions of dependent coverage, found a decline in labor supply among young adults, particularly in full-time jobs (Hahn \& Yang, 2016; Depew, 2015). Early analysis of the dependent coverage expansion mandated by the ACA also found evidence of a labor supply effect in terms of the reduced work hours among young workers (Antwi, Moriya, \& Simon, 2013). This evidence suggests that the dependent coverage expansion of the ACA directly affected the labor supply decisions of young adults and increased their likelihood of working part-time. However, some of this labor supply impact had occurred prior to the ACA due to state-level insurance changes.

\subsection{Features of the Massachusetts law}

MA St. 2006, c.58 shares several of the structural features of the ACA that may impact hours of work. These include employer mandates, subsidies for low-income individuals/families, and the establishment of healthcare exchanges. Additionally, the Massachusetts law was accompanied by an expansion of eligibility for coverage of low-income individuals under the state's Medicaid system [known as MassHealth]. Expansion of Medicaid coverage was also offered under the ACA, though not all states have participated in the expansion.

The Massachusetts law required employers with more than eleven full-time equivalent (FTE) ${ }^{3}$ workers to offer pre-tax coverage under at least one health care option and to make a "Fair Share Contribution" (FSC) to the health insurance costs of their employees. The FSC is met if either: 1) $25 \%$ of the firm's full-time employees at Massachusetts locations take up the group plan, ${ }^{4}$ or 2 ) the employer pays a minimum of $33 \%$ of the premium cost. ${ }^{5}$ If employers do not meet the FSC threshold, they must pay into the Commonwealth Care Trust Fund [known as CommCare] an amount not to exceed $\$ 295$ per FTE worker. This fund is used to provide the health insurance premium subsidies for low income individuals and families. Since the FSC threshold is based on the take-up of fulltime workers, Massachusetts employers are not obligated to offer health insurance coverage to part-time employees. One additional feature of the law is that employers with more than eleven FTE workers are subject to

\footnotetext{
2 A recent Congressional Budget Office update on the labor market effects of the Act "estimates that the ACA will reduce the total number of hours worked, on net, by about 1.5 percent to 2.0 percent during the period from 2017 to 2024, almost entirely because workers will choose to supply less labor" (U.S. Congressional Budget Office, 2014). Some of this reduced labor supply may come in the form of workers switching from full-time to part-time employment.

3 The number of FTE workers is calculated as the total annual payroll hours for all employees divided by 2000.

${ }^{4}$ Full-time is the lower of (i) the number of weekly payroll hours to be eligible for "full-time health plan benefits" or (ii) 35 payroll hours per week.

${ }^{5}$ For firms with 51 or more employees, both conditions must be met to avoid the $\$ 295$ payment.
} 
a Free-Rider surcharge if their employees (or employee dependents) exceed certain thresholds for receiving free health care services through MassHealth. ${ }^{6}$

Under the ACA employers with 50 or more FTE workers must provide health insurance for any workers employed more than 30 hours per week. The ACA does not set minimum contributions that employers must make toward insurance premiums. However, the IRS recently ruled out the possibility of firms' "sending their employees to a health insurance exchange with a tax-free contribution of cash to help pay premiums," indicating that such an action would not be in compliance with the ACA and might result in penalties of up to $\$ 100 /$ day per employee (Pear 2014).

The Massachusetts law led to the establishment of a health insurance exchange [known as CommChoice] with eligibility to participate for the following groups: individuals who are not working; workers whose employer does not offer health coverage; workers who are not eligible for their employer's health coverage (i.e. part-time employees, contractors, new hires); and workers who are ineligible for subsidized employer-sponsored coverage (MA St. 2006, c.58). The establishment of the exchange meant that individuals and families could purchase health insurance plans through the exchange if their employment situation (not working, part-time, etc.) meant that health insurance was not available through their employer. The state-level exchanges set up under the ACA also extend the options to purchase health care coverage to workers not eligible for coverage through an employer.

Simply establishing the insurance exchanges did not address whether plans would be affordable for all individuals and families needing to purchase coverage. The Massachusetts law addressed this issue by providing subsidies to cover insurance exchange premiums through the CommCare. Eligibility for subsidies was extended to individuals with incomes below 300\% of the Federal Poverty Level (FPL) who have been Massachusetts residents for at least 6 months, are not eligible for any publicly provided insurance (MassHealth, Medicare, CHIP), and are not provided Employer-Sponsored Insurance (ESI) where the employer covers at least $20 \%$ of premiums for a family plan or $33 \%$ of an individual plan (MA St. 2006, c.58). Under the ACA, individuals are eligible for subsidized purchases through the state insurance exchanges if they have incomes below $400 \%$ of the FPL.

Table 1: Health insurance enrollments in Massachusetts (excludes Medicare)

\begin{tabular}{lrrrrr}
\hline & June 2006 & Dec 2007 & Dec 2008 & Dec 2009 & Dec 2010 \\
\hline Private Group & 4333014 & 4457157 & 4474466 & 4358967 & 4315040 \\
Private individual & 40184 & 65465 & 81073 & 88541 & 95186 \\
MassHealth & 705179 & 764559 & 780727 & 848528 & 898572 \\
CommCare & 0 & 158194 & 162725 & 150998 & 158973 \\
Total & 5078377 & 5445375 & 5498991 & 5446934 & 5467771 \\
\hline
\end{tabular}

Source: Raymond, A.G. (2011). Massachusetts Health Reform: A Five-Year Progress Report. Blue Cross-Blue Shield Foundation of Massachusetts. Retrieved from http://www.power2u.org/downloads/Mass-health-care-reform-2011.pdf

The Massachusetts law passed in April 2006 and was fully implemented by July 2007. In 2006, there were roughly 500,000 uninsured individuals in Massachusetts, or about 7.9\% of the 6.35 million residents. Between June 2006 and the end of 2007,158,194 individuals enrolled in health care coverage through CommCare (the Massachusetts Exchange); another 59,380 obtained coverage through the expansion of MassHealth (the Massachusetts Medicaid program); those purchasing private individual coverage increased by 25,281 ; and the number covered by private group (employer provided) insurance grew by 124,143 (Table 1).

The total increase in individuals covered by the end of 2007 (of 366,998) represents about 73\% of those uninsured in 2006. Between December 2007 and December 2009, those receiving coverage through CommCare remained steady, while those covered by group insurance decreased slightly and those covered by MassHealth increased (Raymond, 2011). These latter two effects are likely the result of the recession during which laid-off workers lost employer-sponsored group coverage and more individuals qualified for Medicaid as incomes fell.

This paper examines the impact of the Massachusetts health insurance reform on part-time employment in that state as a means of predicting the likely impact of the complete implementation of the ACA on hours of work. The hypothesis is that part-time employment increased in Massachusetts (relative to the experience of other states) following the state-level health insurance reforms. The theory suggests such an increase could be labor supply or labor demand driven, affecting voluntary or involuntary part-time employment. The results of the statistical analysis can be used to determine the relative importance of each source of increase in part-time employment.

\footnotetext{
${ }^{6}$ The thresholds are four free-care services for one employee (or employee dependent) or five free-care services among all its employees (or employee dependents).
} 


\section{Data, methods, and findings}

I examine state-level part-time employment data from 1999 to 2012. I do not examine data beyond 2012 as certain components of the ACA were being phased in and may confound my analysis of the Massachusetts law. I treat the 2007 implementation of the new Massachusetts health insurance system as an "experiment" and examine whether it had any differential effect on the growth in part-time employment (both voluntary and involuntary) in Massachusetts relative to the other states. In examining the impact of the Massachusetts health insurance reform, I seek to control for the various factors (other than health insurance availability) which may impact the rate of part-time employment. These include variables affecting the labor demand decisions of firms and the labor supply decisions of workers discussed in the Literature Review section of this paper: 2.1 Understanding Part-Time Employment.

The state-level data were collected into a panel data set of the 50 states plus the District of Columbia for the years 1999 to 2012. Variables include part-time employment (total, voluntary, and involuntary), total employment, male/female employment, employment by age category, state-level unemployment rates, union representation, state-level minimum wages, and employment by industry. Variable definitions and data sources are detailed in Appendix 1.

Table 2 shows summary statistics for all variables used in the analysis (overall means, Massachusetts means, plus minimum and maximum values). From 1999 to 2012, mean voluntary part-time employment is slightly higher in Massachusetts than in the other states while there is no difference in the average rate of involuntary part-time employment. Massachusetts has higher rates of union representation, a larger percentage of employment if food services, and a higher minimum wage than the average of all states. The $\mathrm{min} / \mathrm{max}$ values show that Massachusetts lies within the range of values for all variables.

Table 2: Summary statistics

Variable Means (for Massachusetts and all states)

Minimum and maximum values 1999-2012

\begin{tabular}{|l|l|lll|}
\hline VARIABLE & $\begin{array}{l}\text { MEAN } \\
\text { (ALL } \\
\text { STATES) }\end{array}$ & $\begin{array}{l}\text { MEAN } \\
\text { (MASS) }\end{array}$ & $\begin{array}{l}\text { MIN } \\
\text { (ALL } \\
\text { STATES) }\end{array}$ & $\begin{array}{l}\text { MAX } \\
\text { (ALL } \\
\text { STATES) }\end{array}$ \\
\hline TOTAL \% PART-TIME & 0.184 & 0.215 & 0.096 & 0.254 \\
\hline \% INVOLUNTARY PART-TIME & 0.026 & 0.025 & 0.008 & 0.075 \\
\hline \% VOLUNTARY PART-TIME & 0.146 & 0.178 & 0.068 & 0.212 \\
\hline \% FEMALE EMPLOYED & 0.471 & 0.482 & 0.429 & 0.517 \\
\hline \% YOUNG EMPLOYED & 0.142 & 0.131 & 0.099 & 0.323 \\
\hline \% OLD EMPLOYED & 0.040 & 0.040 & 0.017 & 0.086 \\
\hline \% FOOD SERVING OCCUPATIONS & 0.085 & 0.105 & 0.069 & 0.207 \\
\hline \% UNION REPRESENTED & 0.129 & 0.158 & 0.033 & 0.276 \\
\hline UNEMPLOYMENT RATE & 0.058 & 0.055 & 0.022 & 0.144 \\
\hline STATE MINIMUM WAGE & 6.135 & 7.089 & 5.150 & 9.040 \\
\hline
\end{tabular}

Source: See Appendix for data sources of all variables.

The following figures show the part-time employment rates (total, involuntary, and voluntary) for Massachusetts, all other states (excluding MA), and minimum and maximum values among all states, for each of the years 1999 to 2012 .

Involuntary part-time employment began increasing in 2008 as the economy went into recession. Voluntary part-time employment increased in Massachusetts up to 2007 and then leveled off, while it was decreasing slightly on average in the other states. Total, voluntary and involuntary part-time rates all increased in Massachusetts relative to the average in all other states beginning in 2008 .

Using a panel estimation (including fixed cross-section and period effects), I examine the determinants of part-time employment in the 50 states (plus D.C.) to evaluate whether there was any unexplained change in part-time employment

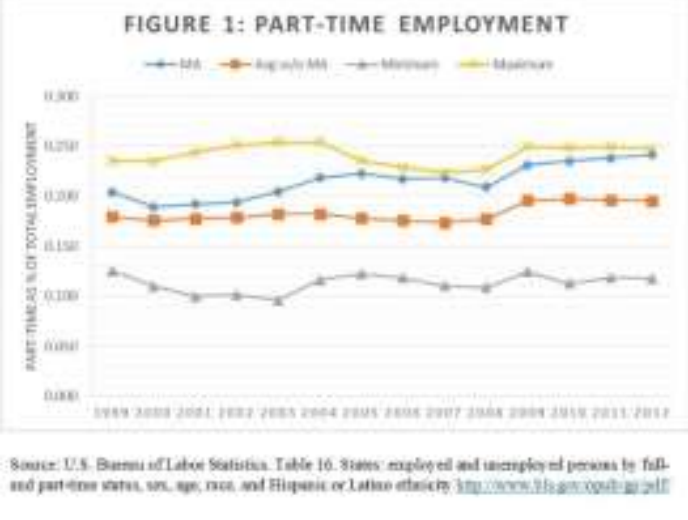



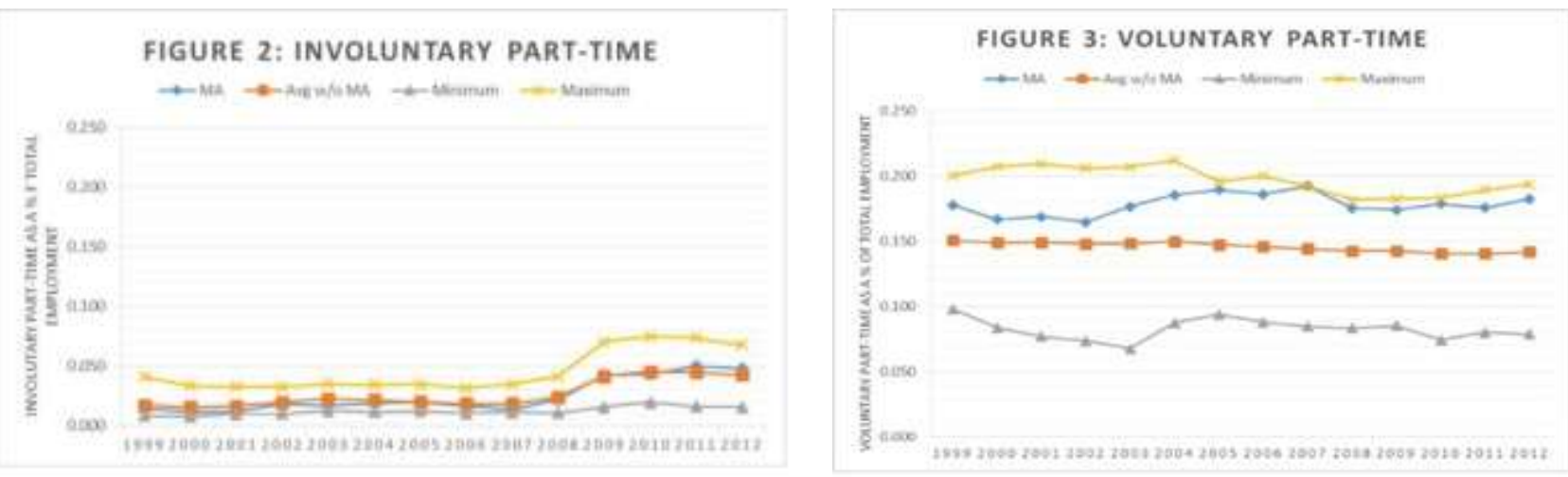

growth (total, voluntary and involuntary) in Massachusetts relative to the other states after the full implementation of health insurance reform in 2007. (The regression results were generated using EViews statistical software.)

Table 3: Results

Method: Panel Least Squares

Sample: 1999-2012, annual data

Periods included: 14 Cross-sections included: 51 (states + DC)

Total panel (unbalanced) observations: 691

\begin{tabular}{|c|c|c|c|}
\hline Dependent Variable: & Total PT & Iavoluatary PT & \begin{tabular}{|l} 
Voluntary PT \\
\end{tabular} \\
\hline Constant & $\begin{array}{l}-0.046 \\
(0.027)\end{array}$ & \begin{tabular}{|l|}
$-0.059^{* 50}$ \\
$(0.013)$
\end{tabular} & $\begin{array}{l}0.016 \\
(0.022)\end{array}$ \\
\hline \%Food Service & $\begin{array}{l}0.169 \\
(0.107)\end{array}$ & $\begin{array}{l}0.144^{\circ 9} \\
(0.054)\end{array}$ & $\begin{array}{l}0.042 \\
(0.089)\end{array}$ \\
\hline \%Female & $\begin{array}{l}0.306^{\circ 00} \\
(0.055)\end{array}$ & \begin{tabular}{|l|}
$0.098^{\text {oro }}$ \\
$(0.028)$
\end{tabular} & $\begin{array}{l}0.185^{\circ+} \\
(0.046)\end{array}$ \\
\hline$\%$ Young $(16-24)$ & $\begin{array}{l}0.097^{\circ+10} \\
(0.028)\end{array}$ & $\begin{array}{l}-0.020 \\
(0.014)\end{array}$ & $\begin{array}{l}0.111^{m+1} \\
(0.024)\end{array}$ \\
\hline \%old $(65+)$ & $\begin{array}{l}0.330^{900} \\
(0.074)\end{array}$ & \begin{tabular}{|l|}
0.049 \\
$(0.037)$
\end{tabular} & $\begin{array}{l}0.249^{p+m} \\
(0.062)\end{array}$ \\
\hline Unempl Rate & $\begin{array}{l}0.579^{* 45} \\
(0.040)\end{array}$ & $\begin{array}{l}0.467^{604} \\
(0.020)\end{array}$ & $\begin{array}{l}0.084^{\circ} \\
(0.034)\end{array}$ \\
\hline$\%$ Union & $\begin{array}{l}-0.039 \\
(0.028)\end{array}$ & $\begin{array}{l}0.024^{4} \\
(0.014)\end{array}$ & $\begin{array}{l}.0 .074^{056} \\
(0.023)\end{array}$ \\
\hline Minimarn Wage & $\begin{array}{l}0.002^{40} \\
(0.001)\end{array}$ & $\begin{array}{l}-0.0004 \\
(0.0005)\end{array}$ & $\begin{array}{l}0.003^{*+\cdots} \\
(0.001)\end{array}$ \\
\hline MAHR dumnyy & $\begin{array}{l}0.010^{24} \\
(0.004)\end{array}$ & $\begin{array}{l}0.003 \\
(0.002)\end{array}$ & $\begin{array}{l}0.008^{*} \\
(0.003)\end{array}$ \\
\hline Adjusted $\mathrm{R}^{2}$ & 0.934 & 0.923 & 0.935 \\
\hline
\end{tabular}

- Statistically significant at the 10 level

$*$ at the 05 level

$\cdots *$ at the .01 level

The results for the panel least squares estimations are presented in Table 3. Three separate estimations are reported corresponding to the three dependent variables: total part-time, involuntary part-time, and voluntary part-time rates (as a percent of total employment). The results are based on 14 years of state-level data [including Washington D.C.] and are estimated using cross-section and year fixed effects.

As expected, the estimated coefficients on \% food service, \% female, \% young, \% old, and the unemployment rate are all positive (except for \% young in the involuntary part-time employment equation). Female, young and older workers are more likely to choose part-time employment [labor supply] and the impact of these variables is stronger in the total and voluntary part-time employment estimations (columns 1 and 3), both in terms of the size of the estimated coefficients and their significance levels. Food service establishments are more likely to employ part-time workers [labor demand] and the estimated coefficient on this variable is significant only in the involuntary part-time employment estimation (column 2). The rate of part-time employment is cyclically sensitive, rising during recessions when unemployment is high, and this variable has a much larger effect (in terms of the magnitude of the estimated coefficient) in the involuntary versus voluntary part-time employment 
estimation. ${ }^{7}$ Unionization rates (measured as the percentage of the labor force represented under a union contract) appear to increase involuntary part-time employment but decrease voluntary part-time employment. This could reflect specific language of union contracts or different cyclical responses of highly unionized states. A higher minimum wage is associated with higher rates of voluntary (and total) part-time employment in a state, suggesting that workers find part-time employment more attractive under the higher wage floor. However, a state's minimum wage has no statistically significant effect on involuntary part-time employment.

After controlling for the factors typically associated with part-time employment, the impact of the change in the Massachusetts health insurance system can be evaluated. The Massachusetts Health Reform (MAHR) dummy variable takes a value of 1 for Massachusetts in the years 2007 to 2012, following implementation of MA St. 2006, c.58. The dummy variable takes a value of zero for all other states (all years) and for Massachusetts for the years 1999 to 2006. This variable captures the "treatment" impact of the new law which affected only Massachusetts after reform. The results presented in columns (1) and (3) in Table 3 estimate statistically significant increases of roughly one percentage point in total part-time and voluntary part-time employment rates (coefficients of 0.010 and 0.008, respectively) in Massachusetts after the reform. The results in column (2) show that the health insurance reform had no statistically significant impact on involuntary part-time employment in Massachusetts. An alternative estimation was run to determine if firms cut hours of workers prior to 2007 in anticipation of the law's implementation. The MAHR was adjusted to take a value of 1 starting in 2006, but the estimated results again indicate that the insurance reform had no statistically significant impact on involuntary part-time employment in the state.

\section{Conclusion}

The estimated results reveal that voluntary (and therefore total) part-time employment increased in Massachusetts relative to the other states after the implementation of the state's health insurance reform. Reform measures did not have a statistically significant effect on involuntary part-time employment in the state. These results indicate that the change in part-time employment after the health insurance reform was labor supply rather than labor demand driven. The positive impact of health insurance reform in Massachusetts on voluntary part-time employment suggests that for some workers the pre-reform system was an obstacle to choosing optimal work hours. Implementation of the Affordable Care Act, which provides avenues for obtaining health insurance that are not directly tied to employment, may remove this obstacle for workers in other states and make part-time employment a more attractive choice for workers across the U.S. in the future.

Use of state-level data is one of the limitations of this study. As data on the individual level response to the ACA becomes available, researchers will be able to more definitively estimate the impact of the health insurance reform on part-time employment growth. This individual level analysis would allow for estimations of the labor supply impact of the various components of the ACA [exchanges, Medicaid expansion, etc.]

Given the recent presidential election and current attempts in Congress to "repeal and replace" the ACA, consideration should be given to the potential impact on labor markets of any proposed changes. Labor markets responses may be germane to estimating the explicit costs of any reforms. The opportunity cost of the reforms, particularly changes that might re-institute the "hours lock" previously observed, should be considered as well. The cost of reforms should include their impact on the human capital investment of younger workers (which is facilitated by the expansion of dependent coverage) and on entrepreneurial activities such as new business starts (which may be affected by the availability of health insurance that is not employment based).

\section{References}

Aaronson, D., \& Lubotsky, D. (2014). The Affordable Care Act and the Labor Market. Chicago Fed Letter No. 323. Antwi, Y.A., Moriya, A.S., \& Simon, K. (2013). Effects of Federal Policy to Insure Young Adults: Evidence from the 2010 Affordable Care Act's Dependent-Coverage Mandate. American Economic Journal: Economic Policy,5(4), 1-28.

Blank, R.M. (1990). Are Part-time Jobs Bad Jobs? In G. Burtless (Ed.) A Future of Lousy Jobs? The Changing Structure of U.S. Wages, (123-55). Washington D.C.: The Brookings Institution.

Cutler, D.M. \& Madrian, B.C. (1998). Labor Market Responses to Rising Health Insurance Costs: Evidence on Hours Worked. RAND Journal of Economics, 29(3), 509-30.

\footnotetext{
7 Involuntary part-time employment rises during recessions as firms cut the hours of their current workforce, bringing some workers to under 35 hours per week threshold, less than they would prefer to work. Voluntary part-time employment may rise during recessions, particularly through an added-worker effect of new labor market entrants working fewer than 35 hours per week.
} 
Depew, B. (2015). The Effect of State Dependent Mandate Laws on the Labor Supply Decisions of Young Adults. Journal of Health Economics, 39, 123-34.

Duffy, A. \& Pupo, N. (1992). Part-time Paradox: Connecting Gender, Work and Family. Toronto: McClelland \& Stewart Inc.

Ehrenberg, R.G., Rosenberg, P. \& Li, J.C. (1988). Part-time Employment in the United States. In R.A. Hart (Ed.) Employment, Unemployment and Labor Utilization, (256-81). Boston: Unwin Hyman.

Gallaway, L. (1995). Public Policy and Part-Time Employment. Journal of Labor Research, 16(3), 305-14.

Garthwaite, C., Gross, T. \& Notowidigdo, M.J. (2014). Public Health Insurance, Labor Supply, and Employment Lock. Quarterly Journal of Economics, 129(2), 653-96.

Gruber, J. (2011a). The Impacts of the Affordable Care Act: How Reasonable Are the Projections? National Tax Journal, 64(3), 893-908.

Gruber, J. (2011b). Massachusetts Points the Way to Successful Health Care Reform. Journal of Policy Analysis and Management, 30(10), 184-92.

Gruber, J. \& Madrian, B.C. (1994). Health Insurance and Job Mobility: The Effects of Public Policy on Job-Lock. Industrial and Labor Relations Review, 48(1), 86-102.

Gruber, J. \& Madrian, B.C. (2004). Health Insurance, Labor Supply, and Job Mobility: A Critical Review of the Literature. In C. McLaughlin (Ed.) Health Policy and the Uninsured (97-178). Washington, D.C.: Urban Institute Press.

Hahn, Y. \& Yang, H. (2016). Do Work Decisions among Young Adults Respond to Extended Dependent Coverage? Industrial and Labor Relations Review, 69(3), 737-71

Hamersma, S. \& Kim, M. (2009). The Effect of Parental Medicaid Expansions on Job Mobility. Journal of Health Economics, 28(4), 761-70.

Heim, B.T. \& Lurie, I.Z. (2015). The Impact of Health Reform on Job Mobility: Evidence from Massachusetts. American Journal of Health Economics, 1(3), 374-398.

Houseman, S. (2001). Why Employers Use Flexible Staffing Arrangements: Evidence From an Establishment Survey. Industrial and Labor Relations Review, 55(1), 149-170.

Jorgensen, H. \& Baker, D. (2014). The Affordable Care Act: A Family-Friendly Policy. Center for Economic and Policy Research Issue Brief.

Kalleberg, A.L., Reskin, B.F. \& Hudson, K. (2000). Bad Jobs in America: Standard and Nonstandard Employment Relations and Job Quality in the United States. American Sociological Review, 65(2), 256-278.

Kolstad, J.T. \& Kowalski, A.E. (2016). Mandate-Based Health Reform and the Labor Market: Evidence from the Massachusetts Reform. Journal of Health Economics, 47, 81-106.

Marshall, K. (2001). Part-time by Choice. Perspectives on Labour and Income, 13(1), 20-27.

Massachusetts Chapter 58 of the Acts of 2006. An Act Providing Access to Affordable, Quality, Accountable Health Care. [cited as MA 2006, St. c.58]. $\quad$ Retrieved from https://malegislature.gov/Laws/SessionLaws/Acts/2006/Chapter58

Mathur, A. Slavov, S.N. \& Strain, M.R. (2015). Has the Affordable Care Act Increased Part-Time Employment? Applied Economics Letters, 23(1-3), 222-25.

Mulligan, C.B. (2014). The Economics of Work Schedules under the New Hours and Employment Taxes. NBER Working Paper No. 19936. (C) 2014 by Casey B. Mulligan.

Owen, L.J. (2015). The Choice of Part-time Employment in the United States and Canada, 1955-2000. Labor History, 56(5), 643-69.

Pear, R. (2014, May 26). I.R.S. Bars Employers from Dumping Workers into Health Exchanges. New York Times, A12.

Pupo, N. \& Duffy, A. (2000). Canadian Part-time Work into the Millennium: On the Cusp of Changes. Community, Work and Family, 3(1), 81-101.

Raymond, A.G. (2011). Massachusetts Health Reform: A Five-Year Progress Report. Blue Cross-Blue Shield Foundation of Massachusetts. Retrieved from http://www.power2u.org/downloads/Mass-health-carereform-2011.pdf

Snider, S. (1995). Characteristics of the Part-Time Work Force and Part-Time Employee Participation in Health and Pension Benefits. Journal of Labor Research, 16(3), 239-48.

Tilly, C. (1991). Reasons for the Continuing Growth of Part-time Employment. Monthly Labor Review, 114(3), 1018.

U.S. Congressional Budget Office. (2014, February). The Budget and Economic Outlook: 2014 to 2024. Publication no. 45010. Retrieved from http://www.cbo.gov/sites/default/files/cbofiles/attachments/45010Outlook2014_Feb.pdf 


\section{Appendix}

\begin{tabular}{|c|c|}
\hline Variable & Data Sources \\
\hline$\%$ Total part-time & $\begin{array}{l}\text { Table 16. States: employed and unemployed persons by full- and part-time status, } \\
\text { sex, age, race, and Hispanic or Latino ethnicity } \\
\text { http://www.bls.gov/opub/gp/pdf/gp12_16.pdf }\end{array}$ \\
\hline$\%$ Involuntary part-time & $\begin{array}{l}\text { Table 16. States: employed and unemployed persons by full- and part-time status, } \\
\text { sex, age, race, and Hispanic or Latino ethnicity } \\
\text { http://www.bls.gov/opub/gp/pdf/gp12_16.pdf }\end{array}$ \\
\hline$\%$ Voluntary part-time & $\begin{array}{l}\text { Table 16. States: employed and unemployed persons by full- and part-time status, } \\
\text { sex, age, race, and Hispanic or Latino ethnicity } \\
\text { http://www.bls.gov/opub/gp/pdf/gp12_16.pdf }\end{array}$ \\
\hline \% Female employed & $\begin{array}{l}\text { Table } 14 \text { States: employment status of the civilian noninstitutional population, by } \\
\text { gender, age, race, Hispanic or Latino ethnicity, and marital status } \\
\text { www.bls.gov/opub/gp/pdf/gp14_14.pdf }\end{array}$ \\
\hline$\%$ Young employed & $\begin{array}{l}\text { Table } 14 \text { States: employment status of the civilian noninstitutional population, by } \\
\text { gender, age, race, Hispanic or Latino ethnicity, and marital status } \\
\text { www.bls.gov/opub/gp/pdf/gp14_14.pdf }\end{array}$ \\
\hline$\%$ Old employed & $\begin{array}{l}\text { Table } 14 \text { States: employment status of the civilian noninstitutional population, by } \\
\text { gender, age, race, Hispanic or Latino ethnicity, and marital status } \\
\text { www.bls.gov/opub/gp/pdf/gp14_14.pdf }\end{array}$ \\
\hline $\begin{array}{lr}\% & \text { Food }\end{array}$ & $\begin{array}{l}\text { Occupational Employment Statistics (OES) Survey } \\
\text { State Occupational Employment and Wage Estimates } \\
\text { http://www.bls.gov/oes/current/oessrcst.htm }\end{array}$ \\
\hline$\%$ Union represented & $\begin{array}{l}\text { Table 5. Union affiliation of employed wage and salary workers by state } \\
\text { www.bls.gov/news.release/union2.t05.htm }\end{array}$ \\
\hline Unemployment Rate & $\begin{array}{l}\text { Table } 14 \text { States: employment status of the civilian noninstitutional population, by } \\
\text { gender, age, race, Hispanic or Latino ethnicity, and marital status } \\
\text { www.bls.gov/opub/gp/pdf/gp14_14.pdf }\end{array}$ \\
\hline Minimum Wage & $\begin{array}{l}\text { Changes in Basic Minimum Wages in Non-Farm Employment Under State Law } \\
\text { https://www.dol.gov/whd/state/stateMinWageHis.htm }\end{array}$ \\
\hline
\end{tabular}

